\title{
Data Management
}

National Cancer Institute

\section{Source}

National Cancer Institute. Data Management. NCI Thesaurus. Code C18086.

Processes for data acquisition, validation, storage, protection, and processing. 